\title{
Sea ice cover in Isfjorden and Hornsund, Svalbard (2000-2014) from remote sensing data
}

\author{
S. Muckenhuber ${ }^{1}$, F. Nilsen ${ }^{2,3}$, A. Korosov ${ }^{1}$, and S. Sandven ${ }^{1}$ \\ ${ }^{1}$ Nansen Environmental and Remote Sensing Center (NERSC), Thormøhlensgate 47, 5006 Bergen, Norway \\ ${ }^{2}$ University Centre in Svalbard (UNIS), P.O. Box 156, 9171 Longyearbyen, Norway \\ ${ }^{3}$ Geophysical Institute, University of Bergen, P.O. Box 7800, 5020 Bergen, Norway \\ Correspondence to: S. Muckenhuber (stefan.muckenhuber@nersc.no)
}

Received: 22 June 2015 - Published in The Cryosphere Discuss.: 31 July 2015

Revised: 3 December 2015 - Accepted: 24 December 2015 - Published: 19 January 2016

\begin{abstract}
A satellite database including 16555 satellite images and ice charts displaying the area of Isfjorden, Hornsund, and the Svalbard region has been established with focus on the time period 2000-2014. 3319 manual interpretations of sea ice conditions have been conducted, resulting in two time series dividing the area of Isfjorden and Hornsund into "fast ice" (sea ice attached to the coastline), "drift ice", and "open water". The maximum fast ice coverage of Isfjorden is $>40 \%$ in the periods $2000-2005$ and 2009-2011 and stays $<30 \%$ in 2006-2008 and 2012-2014. Fast ice cover in Hornsund reaches $>40 \%$ in all considered years, except for 2012 and 2014, where the maximum stays $<20 \%$. The mean seasonal cycles of fast ice in Isfjorden and Hornsund show monthly averaged values of less than $1 \%$ between July and November and maxima in March (Isfjorden, 35.7 \%) and April (Hornsund, $42.1 \%$ ), respectively. A significant reduction of the monthly averaged fast ice coverage is found when comparing the time periods 2000-2005 and 2006-2014. The seasonal maximum decreases from 57.5 to $23.2 \%$ in Isfjorden and from 52.6 to $35.2 \%$ in Hornsund. A new index, called "days of fast ice" (DFI), is introduced for quantification of the interannual variation of fast ice cover, allowing for comparison between different fjords and winter seasons. Considering the time period from 1 March until end of the sea ice season, the mean DFI values for 2000-2014 are $33.1 \pm 18.2 \mathrm{DFI}$ (Isfjorden) and 42.9 $\pm 18.2 \mathrm{DFI}$ (Hornsund). A distinct shift to lower DFI values is observed in 2006. Calculating a mean before and after 2006 yields a decrease from 50 to $22 \mathrm{DFI}$ for Isfjorden and from 56 to $34 \mathrm{DFI}$ for Hornsund. Fast ice coverage generally correlates well with remote-sensing sea surface temperature and in situ air tem-
\end{abstract}

perature. An increase of autumn ocean heat content is observed during the last few years when the DFI values decrease. The presented sea ice time series can be utilized for various climate effect studies linked to, e.g. glacier dynamics, ocean chemistry, and marine biology.

\section{Introduction}

Svalbard is an Arctic archipelago located between 76 and $81^{\circ} \mathrm{N}$ and $10-34^{\circ} \mathrm{E}$. It is surrounded by the Arctic Ocean in the north, with the Greenland Sea and Fram Strait to the west and the Barents Sea to the east. Spitsbergen is the largest island in the archipelago, and the study area of this work includes two fjords along the west coast of Spitsbergen (Fig. 1).

Water masses along the west side of Spitsbergen are strongly influenced by the West Spitsbergen Current (WSC), that is steered along the slope between the West Spitsbergen Shelf and the deep ocean, the coastal current (CC) on the shelf, and freshwater input from glacier and river runoff along the coastline (Fig. 1). The WSC transports warm and salty Atlantic water (AW) northward, representing the major oceanic heat and salt source for the Arctic Ocean. The WSC contributes strongly to Svalbard's relatively warm climate and causes the eastern Fram Strait to be the northernmost permanently ice-free ocean (Onarheim et al., 2014). The fjords along western Spitsbergen are usually separated from the WSC by the colder and fresher water masses of the northward flowing CC. This, in combination with low temperatures and fresh water input from glacier and river runoff, makes seasonal sea ice growth inside the fjords possible. But 
AW from the WSC can reach the upper shelf and eventually flood into the fjords (Nilsen et al., 2008, 2012). These warm water intrusions have a strong effect on the seasonal sea ice cover inside the fjords. The fjord-shelf exchange is controlled by the density difference between the fjord water masses and the AW, which is determined by the sea ice and brine production during winter (Nilsen et al., 2008). This means that the sea ice cover inside the fjords is not only a result of advected or advecting water masses, but can alter the fjord water significantly and influence the exchange with the shelf.

The aim of this study is to investigate sea ice conditions between 2000 and 2014 in two representative fjords along the west coast of Spitsbergen (Fig. 1), where ocean and atmosphere data are available for further analysis. The two considered fjords are Isfjorden, the largest fjord of Spitsbergen with the size of $2490 \mathrm{~km}^{2}$ (as defined from 2013 Landsat 8 images), and Hornsund, a smaller fjord $\left(320 \mathrm{~km}^{2}\right)$ located in southern Spitsbergen. Both fjords reveal a seasonal sea ice coverage with strong variations between different years. Information about sea ice coverage in Isfjorden has been collected between 1974 and 2008 in Grønfjorden (Zhuravskiy et al., 2012), which is a small sub fjord at the southern entrance of Isfjorden, but no data for the entire fjord area have been published so far. Previous studies have investigated sea ice conditions in Hornsund during the winter seasons of 2005-2011, and the results have been published in Styszyńska and Kowalczyk (2007), Styszyńska and Rozwadowska (2008), Styszyńska (2009) and Kruszewski (2010, 2011, 2012). These studies compare in situ observations from the Polish Polar Station in Isbjørnhamna, a bay at the northern entrance of Hornsund, with atmospheric and oceanic measurements and mean monthly sea ice concentration at the approach to Hornsund. The survey concentrates on regional ice conditions near Isbjørnhamna and no time series for the entire fjord is given.

The data for this article were collected and interpreted within the framework of the Polish-Norwegian AWAKE-2 project. The aim of AWAKE-2 is to understand the interactions between the main components of the climate system in the Svalbard area: ocean, atmosphere, and ice, to identify mechanisms of interannual climate variability and long-term trends. The main hypothesis of AWAKE-2 is that the AW inflows over the Svalbard shelf and into the fjords have become more frequent during the last decades and this results in new regimes and changes in atmosphere, ocean, sea ice, and glaciers in Svalbard. Being a link between land and ocean, Arctic fjords are highly vulnerable to warming and are expected to exhibit the earliest environmental changes resulting from anthropogenic impacts on climate. Sea ice cover is a key parameter for monitoring climate variability and trends since it captures the variability of both ocean and atmosphere conditions. Due to the major role sea ice cover plays in airsea interactions, knowledge about the ice cover is crucial for a better understanding of the Arctic fjord system. The focus

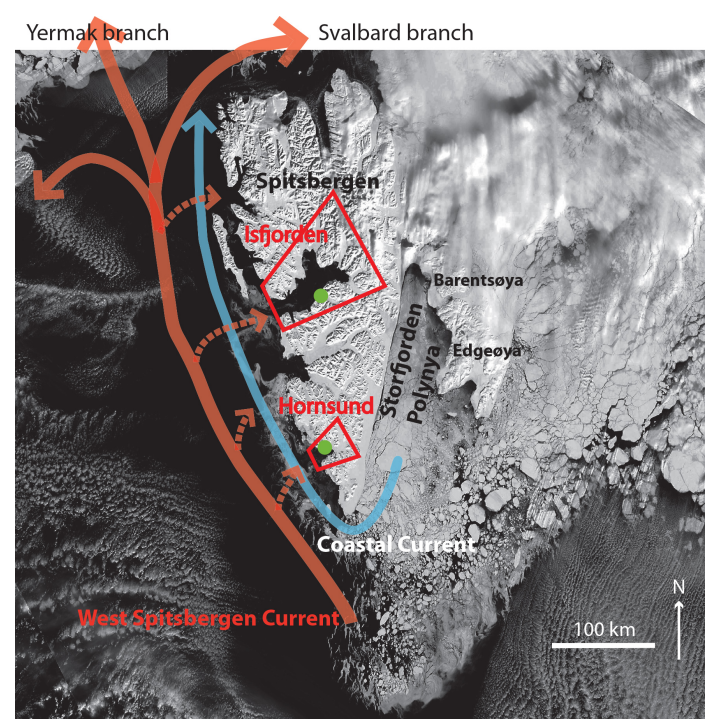

Figure 1. MODIS image of Svalbard taken on 8 April 2009 including a schematic illustration of the ocean currents along western Spitzbergen. The two considered fjords Isfjorden and Hornsund are marked with red polygons. The respective weather stations, marked with green dots, are located at $78.25^{\circ} \mathrm{N}, 15.50^{\circ} \mathrm{E}$ (Isfjorden) and $77.00^{\circ} \mathrm{N}, 15.54^{\circ} \mathrm{E}$ (Hornsund).

of this paper is to present a new sea ice cover time series, revealing the variability in sea ice cover and showing that the observed variability is consistent with other observations. Future studies may be able to use the data set to further understand linkages and drivers of the observed variability.

The paper is organized as follows: Sect. 2 explains the collected satellite images and gives an error estimate for the established sea ice cover time series. A method for manual interpretation of satellite data to describe sea ice conditions in a fjord is introduced in Sect. 3 as well as a new index, the days of fast ice (DFI) index, for quantifying fast ice coverage in a fjord. The sea ice cover time series for Isfjorden and Hornsund, the resulting DFI values and the dates for onset of freezing are presented in Sect. 4 and compared to atmosphere and ocean time series. The discussion can be found in Sect. 5 .

\section{Data}

Investigating sea ice conditions, such as spatial extent and ice type, via satellite remote sensing in comparable small areas like Isfjorden and Hornsund requires a spatial resolution of a few $100 \mathrm{~m}$ or lower. Daily images throughout the year with this resolution are only produced by Synthetic Aperture Radar (SAR), which is an active microwave sensor capable of penetrating cloud cover and taking images during polar night. Since the interpretation of sea ice conditions from SAR images can be ambiguous, high and medium resolution visual/near infrared (VIS/NIR) images provide valuable ad- 
ditional information during polar day. They can also be utilized, if SAR images are not available. However, good temporal coverage with VIS/NIR sensors is only achieved with a resolution above $250 \mathrm{~m}$. Hence, lower accuracy is expected if only VIS/NIR images are utilized.

A satellite database including 6571 SAR images, 9123 VIS/NIR images and 861 ice charts displaying the area of Isfjorden and Hornsund has been established (see Table 1). Focus was placed on the time period 2000-2014, and the part of the season when sea ice was present in the fjords.

NERSC (Nansen Environmental and Remote Sensing Center) maintains a large satellite database including several thousand Level 1 SAR images from ASAR (Advanced Synthetic Aperture Radar on ENVISAT) and Radarsat-2. To select the images which are recorded at the considered region and time period, the NERSC MAIRES online service (http:// web.nersc.no/project/maires/sadweb.py) has been used. 4326 ASAR and 2245 Radarsat-2 sub images covering Isfjorden and Hornsund, respectively, have then been created and stored in GeoTIFF format. The collected SAR data represent a time series from 2005 until 2014 with a temporal resolution of around 1-2 images per day and a spatial resolution between 50 and $150 \mathrm{~m}$.

Medium resolution (300-500 m) VIS/NIR images from MERIS (Medium Resolution Imaging Spectrometer on ENVISAT) and MODIS (Moderate Resolution Imaging Spectroradiometer on Terra and Aqua) covering the Svalbard region have been downloaded from websites hosted by NASA (National Aeronautics and Space Administration). MODIS images from the data sets MOD02HKM (Terra) and MYD02HKM (Aqua) can be ordered pre-processed, which allows all available images of the considered area and time period to be downloaded. A total of 8501 MODIS images represents a temporal resolution of up to several images per day for the period 2000 until 2014. The relevant MERIS images had to be chosen prior to downloading via online "quicklooks" to select images with cloud-free conditions. About 10 MERIS images per year have been chosen and added to the database.

High resolution VIS/NIR images have a distinct lower spatial and temporal coverage, but when available, view the ice conditions with an unmistakable clarity. 335 images from Landsat 1-8 and 161 from ASTER (Advanced Spaceborne Thermal Emission and Reflection Radiometer on Terra) have been chosen for downloading via quicklooks provided by USGS (United States Geological Survey) and the Japan Space System.

In addition to the satellite images, 861 ice charts from the Norwegian Meteorological Institute (met.no) have been added to the database. These ice charts are based on the same satellite images that are used for this paper. The resolution of the met.no ice charts is too low to give sufficient accurate estimates about daily ice conditions in fjords like Isfjorden and Hornsund. Nevertheless, the met.no charts can serve as additional information about the overall sea ice concentra- tion outside the boundary of the high resolution SAR image. Most of the stored ice charts depict ice conditions during polar night when no visual images are available to obtain a quick overview of the large scale sea ice concentration.

To validate and discuss the remote sensing sea ice observations, in situ air, ocean and remote sensing sea surface temperature (SST) data are considered. Monthly SST values are provided by the ESA (European Space Agency) for the time period 1993-2010 with a grid spacing of $25 \mathrm{~km} \times 25 \mathrm{~km}$ (http://catalogue. ceda.ac.uk/uuid/1dc189bbf94209b48ed446c0e9a078af, doi:10.1002/gdj3.20). This data set is used to calculate winter SST for Isfjorden, representing the mean January-April at $78.25^{\circ} \mathrm{N}, 14.75^{\circ} \mathrm{E}$. Moreover, $285 \mathrm{CTD}$ (conductivity, temperature, and depth) profiles taken between 2000 and 2014 at the Isfjorden mouth area $\left(78.08-78.16^{\circ} \mathrm{N}, 13.5\right.$ $14.3^{\circ} \mathrm{E}$ ) and $107 \mathrm{CTD}$ profiles taken between 2009 and 2014 inside Hornsund have been used to calculate the mean heat content of the $25-100 \mathrm{~m}$ depth water column for each year during autumn (July-September). The 25-100 m depth range was chosen in order to avoid the shallow atmospheric heated surface layer and rather concentrate on the layers that represent fjord circulation of either Atlantic water (AW) or Arctic water (ArW). The CTD data were extracted from the UNIS (University Centre in Svalbard) hydrographic database (UNIS HD), where the CTD profiles used in this study are mainly collected by UNIS with additional profiles from the Norwegian Marine Data Centre (NMDC). Air temperature measurements from weather stations in Isfjorden (Svalbard airport, $\left.78.25^{\circ} \mathrm{N}, 15.50^{\circ} \mathrm{E}\right)$ and Hornsund $\left(77.00^{\circ} \mathrm{N}\right.$, $15.54^{\circ} \mathrm{E}$ ) are provided by the Norwegian meteorological institute (eklima.met.no) for the entire observation period. The temperatures of days with average temperature below $-2{ }^{\circ} \mathrm{C}$ between October and May are added together to derive negative degree days for each winter.

Continuity of the presented sea ice time series is expected since VIS/NIR images from the same sensor are considered for the entire observation period. Including SAR as additional data source for the time period 2005-2014 provides useful data during cloud cover and leads to an increased temporal resolution compared to the period prior to 2005, which is solely based on visible data. Visible images are not able to capture sudden sea ice condition changes, if the fjord is covered by clouds. However, complete cloud cover usually did not exceed a few days. The formation and melting of sea ice takes place over time scales of days, but sea ice advection from or into the fjord and break up of fast ice can happen within a few hours. These sudden changes are captured in the time series prior to 2005 on the first succeeding day with little or no cloud cover. 
Table 1. Satellite databases used, including sensor, image type, spatial resolution (i.e. pixel size), amount of collected images, covered time span (i.e. date of first and last image) and source.

\begin{tabular}{llrrll}
\hline Sensor & Image type & Resolution & \# of images & Time span & Source \\
\hline ASAR & SAR & $150 \mathrm{~m}$ & 4326 & 21 Jul 2005-7 Apr 2012 & NERSC database \\
ASTER & VIS/NIR & $15 \mathrm{~m}$ & 161 & 19 Aug 2000-12 Aug 2013 & http://gds.ersdac.jspacesystems.or.jp \\
Landsat 1-8 & VIS/NIR & $15 \mathrm{~m}$ & 335 & 25 Mar 1973-29 Jul 2014 & http:////arthexplorer.usgs.gov \\
MERIS & VIS/NIR & $300 \mathrm{~m}$ & 126 & 25 Jun 2003-7 Apr 2012 & http://oceancolor.gsfc.nasa.gov \\
MODIS & VIS/NIR & $500 \mathrm{~m}$ & 8501 & 25 Feb 2000-4 Aug 2014 & http://ladsweb.nascom.nasa.gov \\
Radarsat 2 & SAR & $50 \mathrm{~m}$ & 2245 & 5 Apr 2011-30 Jul 2014 & NERSC database \\
met.no & ice chart & - & 861 & 24 Oct 2005-27 Jun 2014 & http://polarview.met.no \\
\hline
\end{tabular}
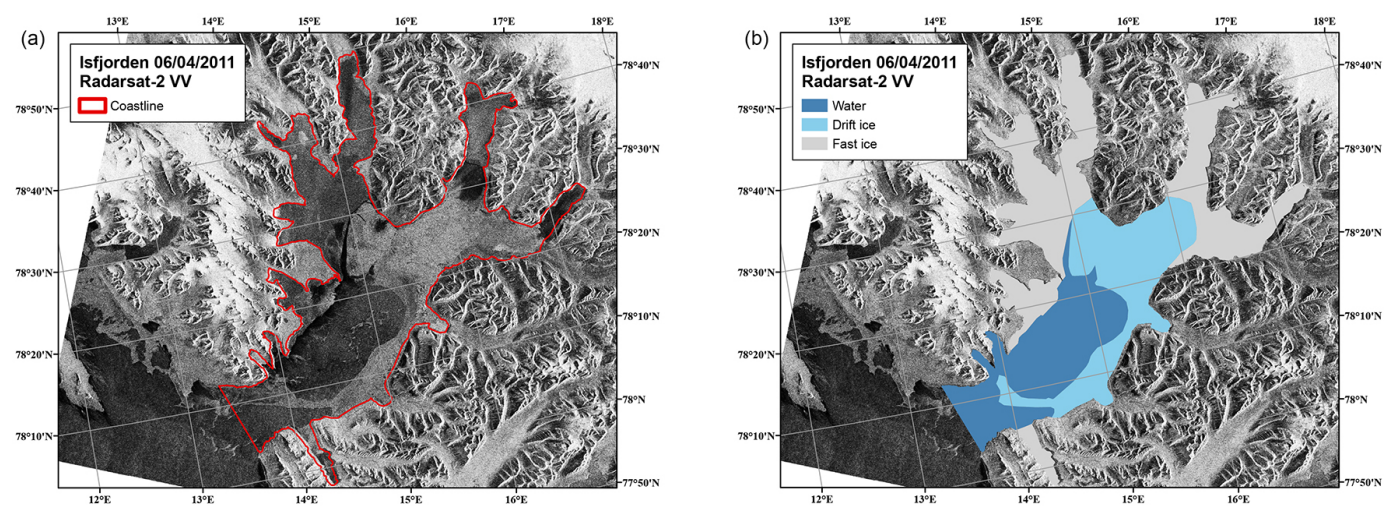

(c)

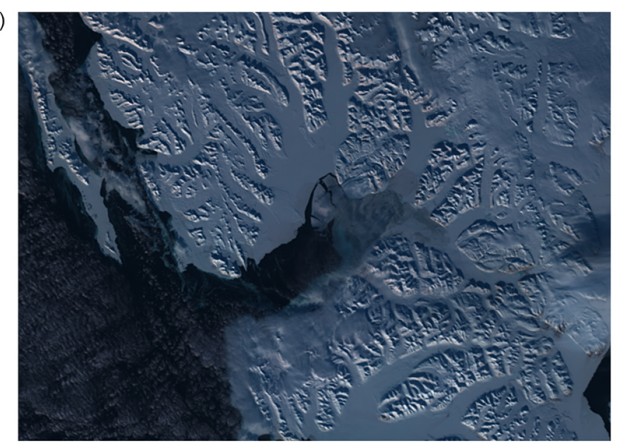

Figure 2. Radarsat-2 (a,b) and MERIS (c) images of Isfjorden taken on 6 April 2011. Radarsat-2 images are shown in ArcGIS with adjusted symbology (a) before and (b) after analysis by a sea ice expert.

\section{Methods}

The downloaded Level 1 satellite data from ASAR, Radarsat2, MODIS, and MERIS were processed with the open-source python toolbox "Nansat" (developed by NERSC) into geoTIFF and PNG Level 2 images, which can be displayed by ArcGIS and several other programs. Within ArcGIS, two polygons covering Isfjorden and Hornsund were created using a high resolution VIS/NIR image from Landsat 8 as reference. This polygon describes the fjord area very accurately and can be subdivided in order to evaluate the sea ice coverage by area. Due to the large amount of considered days and images, the processing chain needed to be fast and efficient.
This was achieved by implementing most steps into a python code working inside ArcGIS.

For the time period 2005-2014, both SAR and VIS/NIR images are available, and the processing chain for a specific date (leading to one data point in the time series) is as follows. The SAR images of the considered day are loaded into ArcGIS, and their symbology is adjusted to increase the visual difference between water and ice. Then the mentioned polygon is superimposed on the images and divided by a sea ice expert into the regions "fast ice", "drift ice", and "open water" (Fig. 2a, b). Both "fast ice" and "drift ice" appear white on the visible image and are characterized by high backscatter values on the SAR image. "Open water" appears dark blue on the visible image and has low/high SAR 
backscatter values during low/high wind speeds. "Fast ice" is attached to the coastline and does not change its position on consecutive SAR images. This makes it easy to identify "fast ice", but the difference between "drift ice" and "open water" can be ambiguous during high wind speeds, if only SAR data are available. The origin of the sea ice, which can result from both freezing inside the fjord or advection from the shelf, is not considered during the manual interpretation. The area of each region is calculated in $\mathrm{m}^{2}$ using a built in function of ArcGIS, and the results are saved in a text file. In case VIS/NIR images are available for the same date, they are used for validation and interpretation support of the SAR images (Fig. 2c).

Prior to 2005, no high quality SAR images could be accessed, and the time series is solely based on VIS/NIR images. During polar night it is therefore not possible to describe the ice conditions. During polar day high accuracy is only achieved for days with high resolution VIS/NIR images and lower accuracy is expected for the other days, due to the lower resolution of MODIS and MERIS compared to SAR. The method yields still high reliability for the analyzed years before 2005 since water and ice can be separated unmistakably on visual images. Continuity of the time series is expected since MODIS, Aster, and Landsat data are available and considered for the entire time series.

\subsection{Days of fast ice (DFI)}

To quantify sea ice coverage in a defined region (in our case Isfjorden and Hornsund), a new index called "days of fast ice" (DFI) is introduced. The index describes fast ice conditions over a considered time period in a single value with unit days. Both temporal and spatial extent of the fast ice is included. The DFI are calculated by building the sum over the fast ice area of all considered days relative to the total area, i.e. in our case the entire fjord area (Eq. 1).

$\mathrm{DFI}=\sum_{\text {days }} \frac{\text { fast ice area }}{\text { total area }}$

The unit days shall give a quick understanding of the range (considered time period) and linear scaling. The index indicates the number of days that the fjord would be covered $100 \%$ with fast ice. The DFI values allow a simple comparison between different regions and time periods as well as with external parameters like atmospheric or oceanic data.

\subsection{Error estimates}

Since the time series is based on manual interpretation, defining an exact error value for spatial sea ice extent is not possible. Nevertheless, possible error sources can be evaluated and an error estimate from the analyzing sea ice expert can be given.

The biggest error source is wrong interpretation of ambiguous SAR images during polar night, when no visible im- ages are available for validation. As mentioned above, "fast ice" is easy to identify, whereas the separation of "drift ice" and "open water" is sometimes inconclusive. This error for "drift ice" and "open water" is hard to quantify, but can be up to $10 \%$ and in some cases even more.

The different resolutions of the utilized satellite images is another potential source of error. In our study, the areas covered by "fast ice", "drift ice", and "open water" do not vary randomly from pixel to pixel, but are usually divided by defined edges. Using different resolutions should not affect the classification of a certain region but only the accuracy of the edge position in the order of one pixel. Hence, a relative error estimate can be given by multiplying the edge length with the pixel size and dividing the result by the fjord area. Assuming an edge of $20 \mathrm{~km}$ and $7 \mathrm{~km}$, which is about the fjord width of Isfjorden and Hornsund, and a resolution range of $15 \mathrm{~m}$ (Landsat, ASTER) to $500 \mathrm{~m}$ (MODIS), the resulting error range is $0.01-0.4 \%$ for Isfjorden and $0.03-1 \%$ for Hornsund.

Insufficient geographic information for the satellite image can lead to a slightly stretched satellite image compared to the fjord polygon in the order of a few pixels. This can lead to an additional error of the same order of magnitude as the discussed resolution error, but only a small number of the satellite images are affected by that

The observed glacier retreat has a negligible effect on larger fjords like Isfjorden, but can change the total area of smaller fjords like Hornsund on the order of $0.5 \%$ per year. Blaszczyk et al. (2013) quantified the total glacier retreat area at the marine margin in Hornsund to be $18.8 \mathrm{~km}^{2}$ between 2001 and 2010 (equal to $5.8 \%$ of the fjord area measured in 2013). The utilized Hornsund coastline was created using a Landsat image from 2013, meaning that the coastline represents the fjord area very well during the later years, but overestimates the total fjord area during the first few years in the order of up to $5 \%$. The glacier covered area along the coastline polygon was not classified separately but added to the surface coverage at the glacier front. This might lead to a slight overestimation of the surface type next to the glacier front, which is most likely "fast ice" during winter. The resulting error is negligible for the second half of the time series and in the order of $0-1 \%$ for the first half.

The daily error estimate based on consideration of the mentioned sources and personal appraisal of the analyzing sea ice expert is in the order of $1 \%$ for "fast ice" and between $1 \%$ up to $10 \%$ for "drift ice" and "open water" depending on the availability of VIS/NIR images for validation. The error propagation from a single day to a time period of several months leads to a very high accuracy for all given monthly averaged fast ice cover and days of fast ice (DFI) values. The error of these values are therefore not considered in the following since they do not influence the interpretation of the results. 
Table 2. Calculated "days of fast ice" (DFI) for Isfjorden and Hornsund between 2000 and 2014 for two different time periods. "Total season" refers to the entire sea ice season starting during autumn of the previous year and "short season" refers to 1 March until the end of the ice season, i.e. the time period when VIS/NIR images are available. $\Delta$ describes the difference between the entire and short season.

\begin{tabular}{l|rrr|rrr}
\hline (DFI) & \multicolumn{3}{|c|}{ Isfjorden } & & \multicolumn{2}{l}{ Hornsund } \\
Year & Total season & Short season & $\Delta$ & Total season & Short season & $\Delta$ \\
\hline 2000 & - & 46.0 & & - & 56.7 & \\
2001 & - & 33.8 & - & 54.3 & \\
2002 & - & 52.2 & & - & 53.6 & \\
2003 & - & 43.1 & - & 53.5 & \\
2004 & - & 70.7 & & - & 59.9 & \\
2005 & - & 55.4 & & - & 56.0 & \\
2006 & 19.4 & 9.5 & 9.9 & 25.8 & 25.8 & 0 \\
2007 & 19.3 & 14.1 & 5.2 & 51.1 & 40.1 & 11 \\
2008 & 28.5 & 20.5 & 8 & 54.2 & 49.8 & 4.4 \\
2009 & 61.6 & 49.8 & 11.8 & 71.4 & 51.4 & 20 \\
2010 & 34.9 & 24.8 & 10.1 & 53.6 & 47.4 & 6.2 \\
2011 & 68.7 & 32.2 & 36.5 & 76.1 & 44.9 & 31.2 \\
2012 & 16.9 & 12.8 & 4.1 & 2.5 & 2.0 & 0.5 \\
2013 & 22.7 & 19.0 & 3.7 & 49.9 & 47.0 & 2.9 \\
2014 & 18.0 & 13.2 & 4.8 & 2.5 & 0.4 & 2.1 \\
Mean \pm SD & $32.2 \pm 18.5$ & $33.1 \pm 18.2$ & $10.5 \pm 9.6$ & $43.0 \pm 25.5$ & $42.9 \pm 18.2$ & $8.7 \pm 9.9$ \\
\hline
\end{tabular}

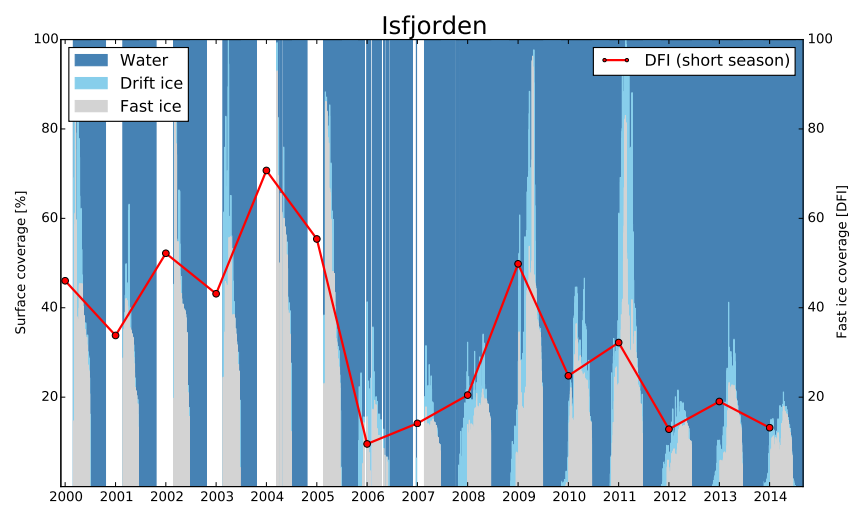

Figure 3. Surface coverage of Isfjorden between 2000 and 2014 divided into "fast ice", "drift ice", and "open water" by a sea ice expert. Total area $=2487.6 \mathrm{~km}^{2}$ (defined with Landsat image from 19 September 2013). White gaps occur when no satellite data were available. The red dots display the "days of fast ice" (DFI) values of the short season as shown in Table 2.

\section{Results}

By utilizing the created satellite database (Sect. 2) and applying the described method (Sect. 3), two time series dividing the area of Isfjorden and Hornsund into "fast ice", "drift ice", and "open water" have been created (Figs. 3 and 4). In total, 3319 manual interpretations of sea ice conditions were conducted by a sea ice expert, leading to an almost daily resolution between 2000 and 2014. Unclassified gaps occur in both time series when SAR images were unavailable during the dark season (white gaps in Figs. 3 and 4).

The daily surface coverage in Isfjorden between 2000 and 2014 is shown in Fig. 3. A maximum fast ice coverage of $40 \%$ and higher is reached in the time periods 2000-2005

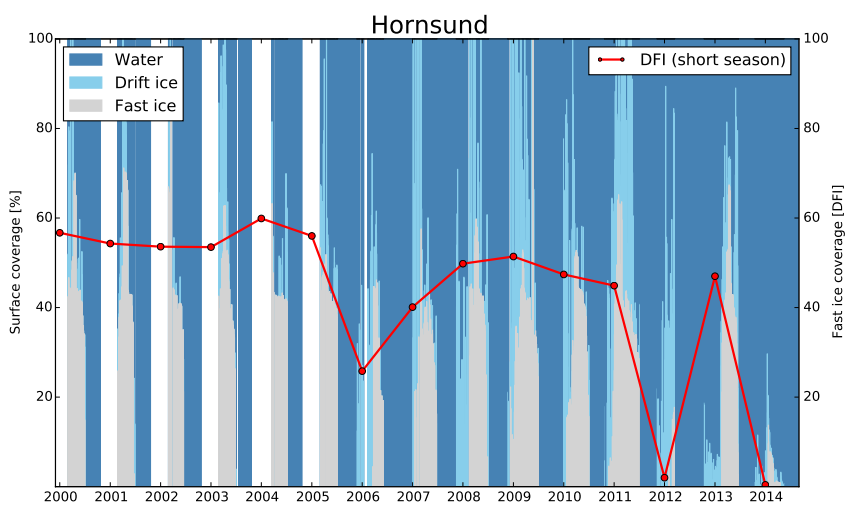

Figure 4. Surface coverage of Hornsund between 2000 and 2014 divided into "fast ice", "drift ice", and "open water" by a sea ice expert. Total area $=324.0 \mathrm{~km}^{2}$ (defined with Landsat image from 24 August 2013). White gaps occur when no satellite data were available. The red dots display the "days of fast ice" (DFI) values of the short season as shown in Table 2.

and 2009-2011. During the periods 2006-2008 and 20122014, the fast ice area stays always below $30 \%$. Figure 4 displays the daily surface coverage in Hornsund for 2000 until 2014. Maximum fast ice cover values above $40 \%$ are reached in all years, except for 2012 and 2014, where the fast ice season is significantly shorter and the maximum stays below $20 \%$. Late growth of fast ice is also observed in 2006, 2008 and 2013.

Monthly averaged fast ice cover, based on the time series shown in Figs. 3 and 4, are shown in Figs. 5 and 6, respectively. The monthly averaged values display the seasonal cycle of fast ice growth and melt/break up in Isfjorden and Hornsund. Values for the dark season (November-February) 


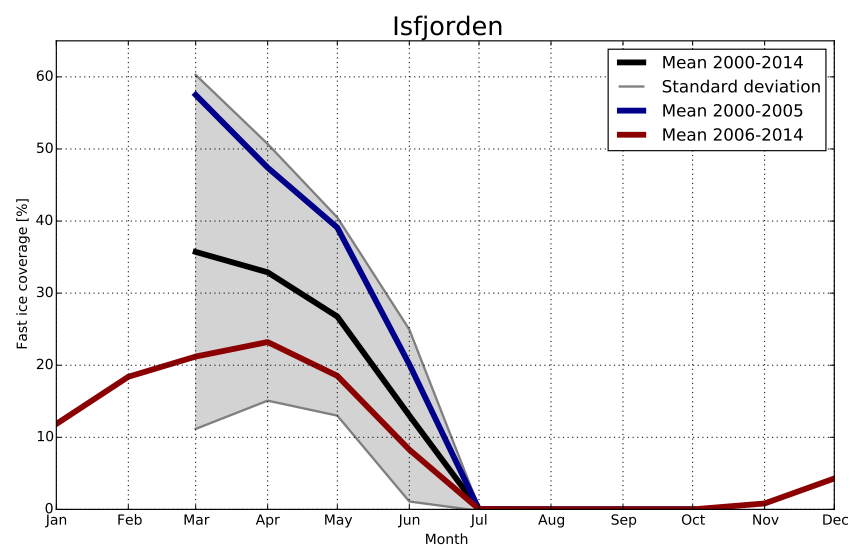

Figure 5. Monthly averaged fast ice coverage in Isfjorden shown for three time periods: 2000-2014 (mean in black and standard deviation in grey) 2000-2005 (blue) and 2006-2014 (red).

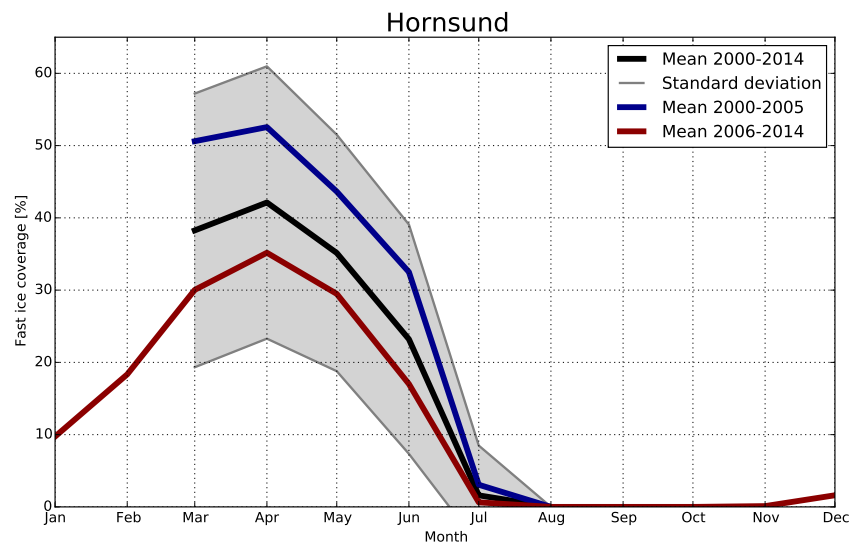

Figure 6. Monthly averaged fast ice coverage in Hornsund shown for three time periods: 2000-2014 (mean in black and standard deviation in grey) 2000-2005 (blue) and 2006-2014 (red).

before 2006 are missing since no high quality SAR images were available for this period.

Less than $1 \%$ monthly averaged fast ice cover were observed in Isfjorden between July and November (Fig. 5). Considering the mean over the entire observation period 2000-2014 (black line, Fig. 5), the highest value is reached in March (35.7\%) or earlier. Before 2005 (blue line, Fig. 5), the value in March is $57.5 \%$. The mean for 2006-2014 (red line, Fig. 5) shows the highest value with $23.2 \%$ in April. Monthly averaged fast ice coverage in Hornsund is shown in Fig. 6. Less than $2 \%$ fast ice is observed between July and November. April is the month with the highest fast ice coverage values: $42.1 \%$ for the mean over all considered years (black line, Fig. 6), 52.6\% for the period 2000-2005 (blue line, Fig. 6) and $35.2 \%$ for 2006-2014 (red line, Fig. 6). Comparing the time periods 2000-2005 and 2006-2014 yields a significant reduction of the monthly averaged fast ice coverage. The seasonal maximum decreases by 60.2 and $33.1 \%$

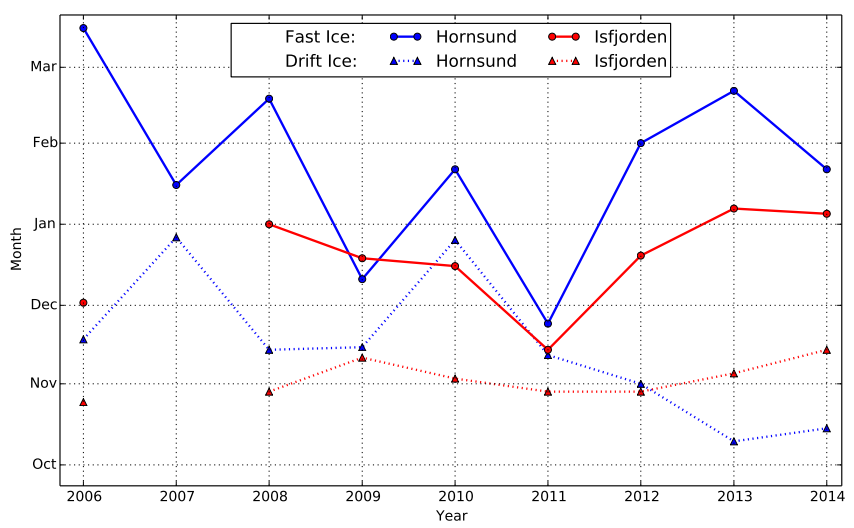

Figure 7. Onset of sea ice cover in Isfjorden and Hornsund. The years refer to the sea ice season, which starts during the previous year, meaning that January marks the beginning of the respective year. The triangles and dots mark the days with first appearance of drift and fast ice, i.e. the start of the sea ice season. Too few satellite images were available for Isfjorden in 2007 to give a reliable estimate.

(relative to the value for 2000-2005, assuming the maximum occurs in March) in Isfjorden and Hornsund, respectively.

\subsection{Days of fast ice (DFI)}

Utilizing Eq. (1) and the time series shown in Figs. 3 and 4, DFI values have been calculated for Isfjorden and Hornsund, and the results are shown in Table 2. For each sea ice season, two different time periods were considered. The "total season" refers to the entire sea ice season, which lasts usually from November of the previous year until June, and the "short season" lasts from 1 March until the end of the sea ice season. The "short season" can also be calculated for years in which only VIS/NIR images are available, whereas SAR images are necessary for the "total season".

High correlation coefficients $(R)$ between the total and short season DFI time series for both Isfjorden $(R=0.89)$ and Hornsund $(R=0.94)$ suggest that the short season values effectively capture the interannual variability of the entire season. Only the ice season 2011 shows a higher than average difference in the short and total season DFI values (Table 2), due to very early fast ice growth (Fig. 7) and a high fast ice peak before March.

The DFI mean values (total and short season, Table 2) for Isfjorden are around $10 \mathrm{DFI}$ lower than the mean values for Hornsund, which means around $25 \%$ less fast ice coverage in Isfjorden relative to the total area of each fjord. Similar high standard deviations for both fjords indicate strong variations from year to year.

Both "short season" time series show a strong decrease in 2006. Isfjorden's DFI values between 2000 and 2005 are all above the mean, whereas after 2006 only 2009 has more than the average "days of fast ice". Calculating a mean before and 
after 2006 shows a drop from 50 to 22 DFI. The situation of Hornsund is similar, yet not so pronounced. The mean value decreases from 56 to 34 DFI before and after 2006. Low values are reached in 2006 and particularly in 2012 and 2014, where the fast ice coverage goes down to almost 0 DFI.

\subsection{Onset of freezing}

The sea ice season in Isfjorden and Hornsund starts usually between late autumn and beginning of winter. Figure 7 shows the days on which drift and fast ice first appear, i.e. the start of the sea ice season in Isfjorden and Hornsund. The year refers to the winter season, which starts during the previous year. This means, that January in Fig. 7 refers to the beginning of the respective year. The first sea ice of the season appears during polar night and SAR images are necessary to define the date of the freezing onset. Since no SAR images were available prior to 2005, the time series in Fig. 7 starts with the sea ice season 2006. Too few satellite images were available to give an reliable estimate of the freezing onset in Isfjorden 2007.

Drift ice starts to grow in Isfjorden in all examined years around the beginning of November. The appearance of fast ice in Isfjorden varies between mid November (2011), December $(2009,2010$, and 2012), and the beginning of January $(2008,2013$, and 2014). The start of the sea ice season in Hornsund underlies stronger variations. The first drift ice of the season was found in November or December in all years except for the last 2 years, during which an early start in October was observed. Fast ice starts to appear in Hornsund between the end of November and mid March. Late fast ice formation was observed during 2006, 2008, and 2013.

\subsection{Ocean and atmospheric data}

In Fig. 8, the DFI values for Isfjorden are compared with satellite-derived winter sea surface temperatures (SSTs) near the mouth of the fjord, ocean heat content from in situ profiles taken at the mouth of the fjord for $25-100 \mathrm{~m}$ depth, as well as winter atmospheric temperatures from a nearby weather station, represented by negative degree days. Fast ice coverage generally correlates well with winter SST and air temperature. The SST time series deviate somewhat in 2003, 2004, and 2006 compared to the observed DFI values, and fast ice coverage in 2011 is relatively low considering the relatively low air temperatures. Low DFI values between 2006 and 2008 are reflected in the ocean heat content time series and a general increase of autumn ocean heat content is observed between 2010 and 2014 when the DFI values decrease.

The DFI values for Hornsund are shown together with autumn ocean heat content and winter atmospheric temperatures in Fig. 9. Except for 2001 and 2010, relatively low/high fast ice cover occurs during winters with relatively high/low air temperatures. The water masses found inside the fjord

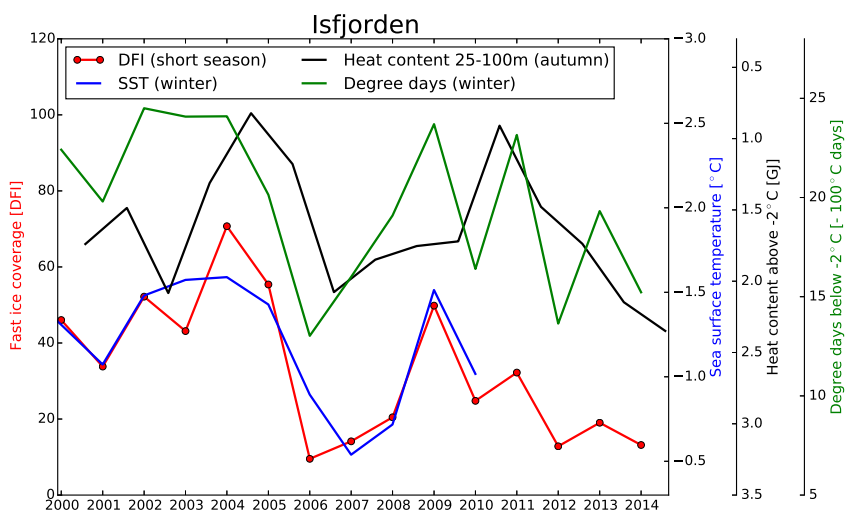

Figure 8. Isfjorden's (red) "days of fast ice" (DFI) values of the short season compared to (blue) winter sea surface temperature (SST), (black) autumn heat content above $-2{ }^{\circ} \mathrm{C}$ of the $25-100 \mathrm{~m}$ depth water column and (green) winter negative degree days below $-2{ }^{\circ} \mathrm{C}$. Winter SST values represent the mean for the period January-April at $78.25^{\circ} \mathrm{N}, 14.75^{\circ} \mathrm{E}$. Heat content values are calculated using the mean temperature profile during autumn (JulySeptember) at the Isfjorden mouth area. Negative degree days have been derived from temperature measurements at the Svalbard airport station $\left(78.25^{\circ} \mathrm{N}, 15.50^{\circ} \mathrm{E}\right)$. Note the reversed SST and heat content axis.

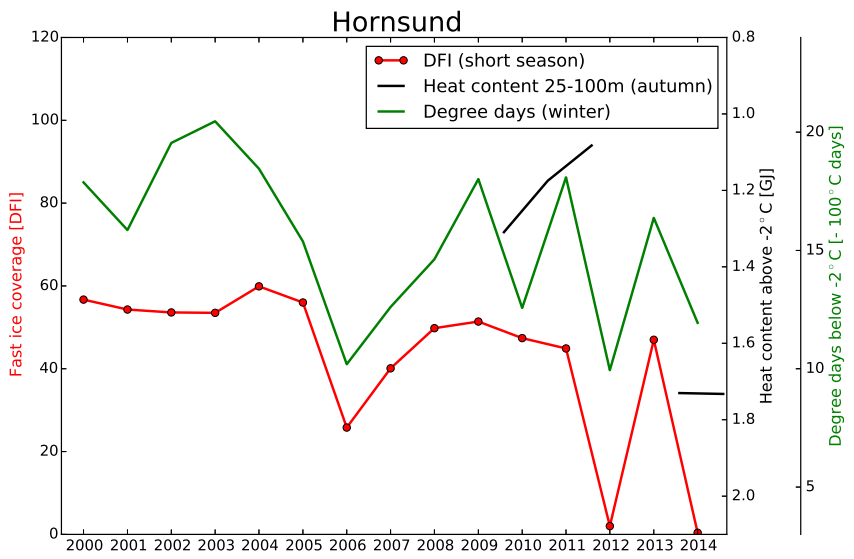

Figure 9. Hornsund's (red) "days of fast ice" (DFI) values of the short season, compared to (black) autumn heat content above $-2{ }^{\circ} \mathrm{C}$ of the $25-100 \mathrm{~m}$ depth water column and (green) winter negative degree days below $-2{ }^{\circ} \mathrm{C}$. Heat content values are calculated using the mean temperature profile inside Hornsund during autumn (JulySeptember). Negative degree days have been derived from temperature measurements at the Hornsund station at $77.00^{\circ} \mathrm{N}, 15.54^{\circ} \mathrm{E}$. Note the reversed heat content axis.

during autumn show a distinct higher heat content in 2013 and 2014 compared to 2009-2011.

\section{Discussion and outlook}

Isfjorden has two periods with relatively high sea ice cover (2000-2005 and 2009-2011, Fig. 3) and two periods with 
relatively low sea ice cover (2006-2008 and 2012-2014, Fig. 3). All periods last 3 years or more, which suggests the involvement of an oceanic mechanism since the atmospheric conditions underlay variations with shorter time scales. However, wind forcing of the West Spitsbergen Shelf (WSS) on timescales from days to months is shown to be one of the mechanisms of starting a shelf circulation of warm AW towards the fjords (Cottier et al., 2007; Nilsen et al., 2012). Cottier et al. (2007) reported that during the Arctic winter of 2005/2006, periods of sustained along-shelf winds generated upwelling and cross-shelf exchange that caused extensive flooding of the coastal waters with warm Atlantic water from the West Spitsbergen Current (WSC) (Cottier et al., 2007). The winter temperature of the WSS reverted to that typical of fall, interrupting the normal cycle of sea ice formation in the region, including both the shelf and the fjords along the west coast of Spitsbergen.

Ongoing hydrographic measurement programs and construction of longer time series (Pavlov et al., 2013) show that fjord systems along west Spitsbergen went from an Arctic state to a more Atlantic water state after winter 2006 (Cottier et al., 2007). In Fig. 8, times series for the winter SST in Isfjorden and the autumn heat content (25-100 m depth) at the mouth of Isfjorden show that both the SST and heat content increased in the period 2006-2008. Atlantic water circulated the WSS and Isfjorden during this period (Cottier et al., 2007; Nilsen et al., 2016) and the surface water seldom reached the freezing point temperature (Fig. 8). Hence, the effect of forcing event on the time scale of weeks (Cottier et al., 2007), and a corresponding advection of AW, can have an influence on the fjord thermodynamics and local sea ice condition on a yearly time-scale. The fjord-shelf system went towards a more Arctic state during the following years, but in 2012, similar forcing events as for 2006 (Nilsen et al., 2016) caused the AW to dominate the fjords again, and the heat content in Fig. 8 shows an increasing trend after 2011. Calculated negative degree-days from atmospheric temperature data closely follows the variation in DFI (Fig. 8) and can also explain the low DFI values in some years. But care must be taken in attributing changes in sea ice cover to atmospheric variability, as reduced sea ice cover and a warmer ocean can also increase the atmospheric temperature.

Another possible explanation for the perennial duration of both small and large fast ice cover years in Isfjorden can be given by looking at the density difference between the fjord water masses and the AW. In contrast to the external forcing mechanism suggested above, this represents a local forcing mechanism through air-ice-ocean interaction. Nilsen et al. showed that a high ice production during winter, results in a higher formation of dense brine-enriched fjord water and the local water masses in the fjord proper can end up being denser than the water masses residing on the shelf (Nilsen et al., 2012). This is a key mechanism that enables AW to penetrate into Isfjorden in spring and the following summer and autumn, and determines in which depth the warm AW will circulate in the water column. Considering Isfjorden as a coastal polynya with the opening area restricted by fast ice cover, more sea ice is produced in winters with less fast ice coverage. Hence, low fast ice coverage can cause AW intrusion in the following summer, which then can lead to low fast ice coverage in the following winter if the intruding AW is circulating high in the water column.

The mechanisms described for Isfjorden could apply for Hornsund, but being a smaller fjord, the resident time for different water masses will be smaller and variations on shorter time scales can be expected. A comparison of the DFI time series in Figs. 8 and 9 suggests that interannual sea ice cover variability in Hornsund may be less influenced by intrusion of AW residing on the shelf. The sea ice cover in Hornsund seems to revert to a "normal" state after a year with known AW intrusion, while Isfjorden is influenced by the AW for several years after such events (Nilsen et al., 2008, 2016). However, Hornsund responds similarly to Isfjorden during the most extreme years of AW dominance on the WSS and strong external forcing mechanisms (Nilsen et al., 2016), i.e. the winters of 2006, 2012, and 2014. Thus, Hornsund, being the most southern fjord along the west coast of Spitsbergen, could serve as an indicator of AW dominance for all fjords north of Hornsund along the west coast. Ocean and atmosphere measurements from the Polish research station in Hornsund carried out by the ongoing Polish-Norwegian project AWAKE-2 (Arctic climate system study of ocean, sea ice and glaciers interactions in Svalbard area) will be utilized within AWAKE-2 to explain the difference between average seasons and years with distinct less sea ice coverage, i.e. 2006, 2012, and 2014 .

Considering the start of the freezing season, i.e. the first appearance of drift or fast ice in the two fjords, Isfjorden shows in general less variability and earlier ice growth (Fig. 7). A low correlation between the start of the freezing season for the two fjords is observed, suggesting a stronger dependence on local conditions rather than a large-scale ocean and/or atmosphere influence. Occurrence of drift ice always precedes fast ice, often with a time lead of 1-2 months. However, care must be taken when defining the start of the freezing in Arctic fjords using satellite images since the first appearance of drift ice will not necessarily reflect that the surface layer of the fjord proper has reached the freezing point temperature, but merely that some protected side fjords within the larger fjord system may have a fresher and colder surface layer, allowing for sea ice production for a limited period. Hence, the true freezing season will start somewhere between the first detection of drift ice and the establishment of fast ice in an Arctic fjord.

Recent observations of the ice cover to the north of Svalbard further demonstrate the intimate link between the heat of the Atlantic water and the distribution of sea ice. Onarheim et al. (2014) have shown that the sea ice area north of Svalbard has been decreasing for all months since 1979 with the largest ice reduction occurring during the winter months at 
a rate of $10 \%$ per decade (Onarheim et al., 2014). This is in contrast to the observed changes in more central parts of the Arctic Ocean, where largest ice decline is happening during summer. However, the observed reduction is concurrent with a gradual warming of $0.3^{\circ} \mathrm{C}$ per decade warming of the AW along West Spitsbergen, and thus, the extra oceanic heat has been the major driver of the sea ice loss, which is concurrent with our results from both Isfjorden and Hornsund. Another indication of warm water as a major driver is the delayed maximum fast ice area in Isfjorden (Fig. 5) from March (or earlier) to April for the 2000-2005 period to the 2006-2014 period, respectively. A warmer water column in late autumn can cause delayed ice formation and consequently lower ice concentrations in early winter.

In conclusion, the presented sea ice time series can be used to obtain a better understanding of interannual variability in Arctic fjord system. Since a sea ice cover reflects the physical state of the ocean and atmosphere, the present sea ice time series can be used in future studies to better understand airice-ocean interaction processes within each fjord system, but also in various climate effect studies linked to, e.g. glacier dynamics, ocean chemistry, and marine biology.

\section{The Supplement related to this article is available online at doi:10.5194/tc-10-149-2016-supplement.}

Acknowledgements. This research was supported by the PolishNorwegian AWAKE-2 (Arctic climate system of ocean, sea ice and glaciers interaction in Svalbard) project (Pol-Nor/198675/17/2013). We thank the developer group of the open-source python toolbox "Nansat" (https://github.com/nansencenter/nansat) and the following agencies/institutes for providing the utilized satellite images and ice charts: National Aeronautics and Space Administration, European Space Agency, and the Canadian Space Agency and Norwegian Meteorological Institute. We would like to thank Ragnheid Skogseth (RS) for preparing and sharing CTD data from the UNIS Hydrographic Database (UNIS HD). The hydrographic data used in this paper are either collected by UNIS or extracted from public databases like The Norwegian Marine Data Centre (NMD at the imr.no). Funding for RS and the construction of the UNIS HD merits REOCIRC (Remote Sensing of Ocean Circulation and Environmental Mass Changes, a Research Council of Norway project no. 222696/F50) and GrønnBille (The Oceanography of Grønnfjorden and Billefjorden, a Research Council of Norway project nr. 227067). A special thanks to the two anonymous reviewers for valuable input that improved our paper.

Edited by: M. Tedesco

\section{References}

Blaszczyk, M., Jania, J. A., Kolondra, L.: Fluctuations of tidewater glaciers in Hornsund Fjord (Southern Svalbard) since the beginning of the 20th century, Pol. Polar Res., 34, 4, 327-352, doi:10.2478/popore-2013-0024, 2013.

Cottier, F., Nilsen, F., Inall, M. E., Gerland, S., Tverberg, V., and Svendsen, H.: Wintertime warming of an Arctic shelf in response to large-scale atmospheric circulation, Geophys. Res. Lett., 34, L10607, doi:10.1029/2007GL029948, 2007.

Kruszewski, G.: Ice condition in Hornsund (Spitsbergen) during winter season 2008-2009, Problemy Klimatologii Polarnej, 20, 187-196, 2010.

Kruszewski, G.: Ice condition in Hornsund during winter season 2009-2010 (SW Spitsbergen), Problemy Klimatologii Polarnej, 21, 229-239, 2011.

Kruszewski, G.: Ice condition in Hornsund and adjacent waters (Spitsbergen) during winter season 2010-2011, Problemy Klimatologii Polarnej, 22, 69-82, 2012.

Nilsen, F., Cottier, F., Skogseth, R., and Mattsson, S.: Fjord-shelf exchanges controlled by ice and brine production: the interannual variation of Atlantic water in Isfjorden, Svalbard, Cont. Shelf. Res., 28, 1838-1853, 2008.

Nilsen, F., Vaardal-Lunde, J., and Skogseth, R.: Topographically controlled flow on the West Spitsbergen Shelf with special emphasis on the Atlantic water transport towards Isfjorden, D:07, ICES CM, 2012.

Nilsen, F., Skogseth, R., Vaardal-Lunde, J., and Inall, M.: A simple shelf circulation model - intrusion of Atlantic water on the West Spitsbergen Shelf, J. Phys. Oceanogr., accepted, 2016.

Onarheim, I., Smedsrud, L., Ingvaldsen, R., and Nilsen, F.: Loss of sea ice during winter north of Svalbard, Tellus A, 66, 23933, doi:10.3402/tellusa.v66.23933, 2014.

Pavlov, A., Tverberg, V., Ivanov, B., Nilsen, F., Falk-Petersen, S., and Granskog, M.: Warming of Atlantic water in two West Spitsbergen fjords over the last century (1912-2009), Polar Res., 32, 11206, doi:10.3402/polar.v32i0.11206, 2013.

Styszyńska, A.: Ice condition in Hornsund and its foreshore (SW Spitsbergen) during winter season 2007/2008, Problemy Klimatologii Polarnej, 19, 247-267, 2009.

Styszyńska, A. and Kowalczyk, M.: Ice condition in Hornsund and its foreshore (SW Spitsbergen) during winter season 2005-2006, Problemy Klimatologii Polarnej, 17, 147-158, 2007.

Styszyńska, A. and Rozwadowska, A.: Ice condition in Hornsund and its foreshore (SW Spitsbergen) during winter season 2006/2007, Problemy Klimatologii Polarnej, 18, 141-160, 2008.

Zhuravskiy, D., Ivanov, B., and Pavlov, A.: Ice conditions at Gronfjorden Bay, Svalbard, from 1974 to 2008, Polar Geogr., 35, 169176, doi:10.1080/1088937X.2012.662535, 2012. 